\title{
Rivoletti, Christian.
}

Ariosto e l'ironia della finzione. La ricezione letteraria e figurativa dell'Orlando furioso in Francia, Germania e Italia.

Venice: Marsilio, 2014. Pp. xxx, $433+14$ b/w and 23 colour ill. ISBN 978-88317-02111-0 (paperback) €35.

The concept of "irony" and the Italian Renaissance poem Orlando furioso by Ludovico Ariosto (1474-1533) constitute a solid couple for scholars and critics today. If we carefully examine the history of the reception of Ariosto's masterpiece over the centuries, however, we receive a totally different impression: the ironic aura of Orlando furioso, when not neglected, was used by classicist theorists to criticize Ariosto's infringements on pseudo-Aristotelian principles of literary verisimilitude. Only exceptional figures in Europe grasped, and then capitalized on, the potential of Furioso's original elements.

In this rich volume, Christian Rivoletti analyzes the poem by Ariosto in light of the fortune (and misfortune) of the notion of "ironia della finzione" (fiction irony), which mainly consists of a stylistic attitude that the narrator of the Orlando furioso deploys to dialectically interact with the poem. Ariosto gives his readers a sense of truth by narrating facts that hold literary and historical traditions - while at the same time distancing himself. It is in such a space that irony finds its natural habitat.

In the first chapter, Rivoletti illustrates the various layers of Ariosto's irony and locates five: the first two refer to historical reality and the literary as well as artistic tradition that came before Ariosto, whereas the following three emanate from the poem itself. They are displayed at the level of inventio (e.g., when the narrator comments on the plot), dispositio (how the poem is structured in cantos with introductory stanzas, flashbacks, etc.), or elocutio (metres and rhymes, wits, rhetorical tools).

In chapters 2 and 3, the author dwells on two instances where Ariosto's example was followed not only in terms of stylistic emulation but also in terms of writing attitudes. French literati La Fontaine (1621-95), author of a series of Nouvelles (then Contes et nouvelles) en vers tirées de Boccace et de l'Ariosto (first edition, 1664), and Voltaire (1694-1778) perfectly grasped the procedures of Ariosto's irony. With Voltaire, we also have the case of a learned man who at the beginning blamed Ariosto for violating Aristotelian poetics, but who later on realized the originality of Furioso's status as an epic poem that mixes different 
tones, registers, and genres. According to Rivoletti, the disregarded poem La Pucelle d'Orléans (published in 1762) is where Voltaire's attempt to reproduce Ariosto's style reached its peak by simulating a real source for the text in the person of Tritême-as Ariosto had done with Turpino.

The fourth chapter shows how the work of Ariosto was evaluated by eighteenth-century German writers-such as Christoph Martin Wieland (1733-1813) - who finally recognized in the Furioso a new type of epic poem that Rivoletti names "Ariostesque-romantic," whose first traces can be located in Wieland's Idris und Zenide (unfinished, 1768), Der neue Amadis (1771), and Oberon (1780). In such poems, Ariosto works as an inspiring force together with Sterne's novels, thus demonstrating a continuity between two genres that Romanticism was to highlight.

Developing the theoretical reflection by Friedrich Schiller (1759-1805) on modern poetry, and by Johann Gottlieb Fichte (1762-1814), Friedrich Schlegel (1772-1829) for the first time did justice to Ariosto's masterpiece from many points of view. In chapter 5, we are told that Schlegel realized the mixture between serious and comic tones, and compared the poem's structure to a pictorial "grottesca" or arabesque. Moreover, in the analysis of Schelling (17751854), the role of the author was comprehended for his power to dominate (and not be dominated by) a various and multifarious subject. Unfortunately, Schlegel's critical gains were then overturned by the negative vision that Hegel (1770-1831) carried out of Romantic aesthetics, when in fact he used the concept of irony to assess Ariosto's poetry-which is why further critics dated to Hegel (and not to Romantics) the elaboration of that critical paradigm.

The names of celebrated Italian critics Francesco De Sanctis (1817-83), Luigi Pirandello (1867-1936), and Italo Calvino (1923-85) appear in the sixth chapter, where Rivoletti illustrates the attention paid to Ariosto's irony in contemporary criticism after Hegel. If De Sanctis made irony one of the interpretative categories in a close reading of Ariosto's verse, Pirandello adopted Romantic ideas, and in a rather debatable way countered Furioso (irony) with Don Quijote (humour). Calvino in turn capitalized on Furioso's lesson and the corresponding narrator's gaze in his own novel on Italian Resistance, Il sentiero dei nidi di ragno (The path to the spiders' nests), published in 1947.

The seventh chapter includes a series of examples of painting through the centuries, where the artists tried to translate into pictures the irony of the epic poet. Rivoletti examines the first illustrated editions of the poem 
(Venice: Giolito, 1542; Valgrisi, 1556; and Franceschi, 1584), and how the illustrators chose to either isolate or put together the episodes of the relevant canto. In addition to other paintings, Rivoletti dwells on the plates that Jean Honoré Fragonard (1732-1806) dedicated to Orlando furioso in an attempt to immortalize both Ariosto as narrator and the limited perspective of the characters in various scenes.

In the last pages, detailed bibliographical appendices complete the volume, including all essays mentioned in the book.

Through a very detailed, interdisciplinary, and updated analysis of Ariosto's masterpiece, Rivoletti delineates the phases of the history of a peculiar kind of irony that lived in a Renaissance poem and later, both in its critics and in another vital literary genre. Although not immediately understood in its whole refined complexity, the Orlando furioso does not cease to speak to its readers and to exhibit its extraordinary modernity.

JOHNNY L. BERTOLIO

University of Toronto

\section{Roudaut, François.}

Sur le sonnet 31 des Regrets. Éléments d'histoire des idées à la Renaissance. Paris: Classiques Garnier, 2014. Pp. 272. ISBN 978-2-8124-3251-4 (paperback) $€ 29$.

François Roudaut's monograph Sur le sonnet 31 des Regrets. Éléments d'histoire des idées à la Renaissance provides a detailed structural reading of Les Regrets' famous sonnet and places the poem in conversation with contemporary and classical sources. This second component takes up the bulk of the work; with the help of relevant intertexts, Roudaut traces the genealogy of the sonnet's words and suggests various frameworks for their interpretation. It is through this rich web of terms and ideas that Roudaut gives us a glimpse of how the poem might have been read at the time of its publication.

As Roudaut explains, Du Bellay composed Les Regrets during his stay in Rome where he served as steward for the cardinal Jean Du Bellay, but he only published the collection together with a series of other works upon his return to France in 1558. The sonnet central to Roudaut's study explicitly 